\title{
EVALUATION OF DIFFERENT EXOTIC SUGARCANE GENOTYPES
}

\author{
Khaliq Abdul*, Yasin Muhammad, Afzal Muhammad Shehzad, Ahmad Naeem \\ Sugarcane Research Institute, Faisalabad \\ *E-mail: khaliq1775@gmail.com
}

\begin{abstract}
This research was conducted at research area of Sugarcane Research Institute (Faisalabad, Pakistan) to evaluate the best sugarcane clones amongst twenty eight clones against two standard varietiesHSF-240 and CPF-249 for different agronomic traits and yield characters during the crop season of 2016-2017 at third selection stage of variety development. In the experiment, three clones (S2014-SL-1322, S2014-SL-1359, S2014-SL-1372) out of twenty eight $(11 \%)$ were selected on the basis of good performance and did not show splits, lodging tendency, pithiness, aerials roots, disease infestation and these showed good crop stand and thick canes. These three clones were promoted to next stage of variety development cycle. In set-1, Clone S2014-SL-347 gave higher cane yield $\left(58.37 \mathrm{t} \mathrm{ha}^{-1}\right)$ with sugar yield of 7.18 tha $^{-1}$. But it showed some characters of high aerial roots and pithiness and so rejected. In set-II, the clone S2014-SL-1224 gave higher cane yield of 71.51t ha-1 with $8.73 \mathrm{t} \mathrm{ha}^{-1}$ sugar yield and showed high disease infestation of red rot and smut and so rejected. But S2014SL-1322, S2014-SL-1359, S2014-SL-1372 produced cane yield of $71.37 \mathrm{t}$ ha-1, $68.56 \mathrm{t} \mathrm{ha}^{-1}$, $67.33 \mathrm{t} \mathrm{ha}^{-1}$ with $8.71 \mathrm{t} \mathrm{ha}^{-1}, 8.34 \mathrm{t} \mathrm{ha}^{-1}, 8.31 \mathrm{t} \mathrm{ha}^{-1}$ sugar yield respectively. The remaining twenty five clones $(89 \%)$ out of twenty eight were rejected due to diseases susceptibility, lodging, pithiness, poor crop stand, aerial roots and high splits.
\end{abstract}

\section{KEY WORDS}

Aerial roots, clone, smut, fuzz, pithiness.

Global interest in sugarcane has increased significantly in recent years due to its economic impact on sustainable energy production. Sugarcane breeding and better agronomic practices have contributed to a huge increase in sugarcane yield in the last 30 years.

Sugarcane is the main sugar-producing crop (Junejo et al., 2010).This crop plays a pivotal role in economy of Pakistan in order to drive the large sugar industry. It has $0.7 \%$ share to Gross Domestic Product. In the Punjab, during 2016-17, sugarcane was grown on an area of 791.94 thousand hectares as compared to 705.35 thousand hectares planted previous year. This shows an increase of $12.30 \%$ over the last year. The production was 47.96 million tones as compared to 41.97 million tonnes of the previous year. The production thus shows an increase of $14.30 \%$ over the previous year (Anonymous, 2017).

Sugarcane is cultivated in many of the world countries with Brazil as a major producer followed by India, China, Pakistan, Thailand and Mexico (FAO, 2010). It provides employment and by products for industrial sector. The sugar industry is second to textile in Pakistan which is primarily based on the mercy of sugarcane cultivation (Bahadar et al., 2002). It is also an important cash crop of Pakistan (Ahmad et al., 1991), which plays an important role in economic uplift of farmers.

In Pakistan about $99 \%$ of the sugar is extracted from sugarcane to meet the demand at domestic level (Azam and Mukarram, 2010). The average per hectare yield in Pakistan is less than other cane growing countries of the world (Sohu, et al., 2008). One and major reason for that, is our farmers do not have option regarding high yielding varieties (Majeedano, et al., 2003).

The cane and sugar yield of sugarcane crop can be improved with high yielding varieties and better agronomic practices (Heinz, 1987). Sugarcane crop improvement in many countrieslies on conventional breeding, mutation breeding, somaclonal variation and genetic engineering (Dalvi et al., 2012). 
Sugarcane improvement through conventional methods is dependent on the nature of flowering, viability of pollen and seed (Moore and Nuss, 1987; Khan et al., 2008) and the genomic complexity of sugarcane crop (Ingelbrecht et al., 1999).

Sugarcane having complex genome, low fertility and large genotype $\mathrm{x}$ environment interactions make traditional varietal improvement and genetic studies difficult and laborious (Mendoza, 2000).

In Pakistan, the flowering and seed set under natural conditions is a very serious problem in sugarcane that hampers varietal improvement. The basic facilities for hybrid seed production and variety development are lacking in the country. Though the coastal belt in Sindh, is blessed with specific climatic conditions where sugarcane plants flower. But at local spots where plants flower, non-synchronization in genotypes for cane flowering reduces the possibility of hybridization (Tiawari et al., 2009).

Therefore, sugarcane variety development in Pakistan is mainly based on import of germplasm from the cane breeding stations abroad and also through exotic or locally collected fuzz (Kaloi et al., 2007).Most of breeding material was imported from USA, Sri Lanka and Mauritius.

In cane breeding program in Pakistan, large numbers of seedlings are grown from fuzz (true seed), selections are made in subsequent generations to obtain superior clones/genotypes for release as new varieties. The development of new sugarcane varieties is not possible in Pakistan because of intricate flowering of the plant and non-availability of sugarcane breeding facility and acclimatization (Javid et al., 2001).

Thus the selection is the base line to cane agronomist in Pakistan to develop new varieties. Potential of new genotypes needs to be tested in local environment before deciding to release as a new cultivar in a particular region (Khan et al., 2000).

All the selection phases are important varietal development cycle but establishment of a good nursery is of prime importance. Keeping in view the importance of nursery, the present study was conducted to evaluate the best sugarcane genotype in agro climatic condition of Faisalabad, Pakistan.

\section{MATERIALS AND METHODS OF RESEARCH}

The research project was conducted at the farm area of Sugarcane Research Institute (Faisalabad, Pakistan) during crop season 2016-17. Two sets of preliminary varietal yield trial consisting of 28Sugarcane clones and two check varieties HSF-240 and CPF-249 were laid out in randomized complete block design with three replications. Experiment was sown on 10-10-2016 with net plot size of $4 \mathrm{~m} \times 3.6 \mathrm{~m}$ by keeping inter-row spacing of $120 \mathrm{~cm}$. All the agronomic and cultural practices were applied as and when considered necessary during the course of study.

The seed rate of 75,000 double budded setts per hectare was used and crop was planted in $120 \mathrm{~cm}$ apart double row strips. Trenches were made with the help of tractor drawn ridger. Fertilizer was applied at the rate of 168, 112 and $112 \mathrm{~kg}$ NPK per hectare. Twenty irrigations (80 acre inches) were applied at different intervals according to the crop need and climate.

Data recording. Emergence and tillers per plot was counted at 45 days and 90 days after planting respectively. Number of canes was counted from the two strips in each plot at final harvest and was converted to canes per hectare. Crop was harvested at maturity by taking an area of two strips from each plot and cane yield per hectare was estimated.

During selection, different crop parameters were also observed. It includes pithiness, lodging, aerial roots, splits disease infestation (smut, rust) and growth performance / crop stand of clones. These parameters were observed visually and noted. The observation of these parameters is of great concern for promotion and rejection of clones to next stage of variety development.

Statistical analysis. The data collected were subjected to Fisher's analysis of variance technique and LSD test at $0.05 \%$ was used to compare the differences among treatment means (Steel \&Torrie, 1984). 


\section{RESULTS AND DISCUSSION}

The results are summarized in Table 1 and Table 2 . In set-I, 14 clones along with two standard varieties HSF-240 and CPF-249 were studied out of which Clone S2014-SL-347 gave higher cane yield $\left(58.37\right.$ tha $\left.^{-1}\right)$ with sugar yield of 7.18 tha $^{-1}$. But it showed some bad characters of high aerial roots and pithiness and so rejected. Similarly in this set remaining 13 others were also rejected due to smut, red rot, pithiness, aerial roots, high splits and poor growth performance.

Table 1 - Set-I

\begin{tabular}{|c|c|c|c|c|c|c|c|}
\hline Sr.No. & $\begin{array}{l}\text { Variety / } \\
\text { Clone }\end{array}$ & $\begin{array}{c}\text { Germination } \\
\%\end{array}$ & $\begin{array}{c}\text { Tillers per } \\
\text { Plant }\end{array}$ & $\begin{array}{c}\text { Cane Count } \\
\left(000 \mathrm{ha}^{-1}\right)\end{array}$ & $\begin{array}{c}\text { Cane Yield } \\
(\mathrm{t} \text { ha- } 1)\end{array}$ & $\begin{array}{c}\text { Sugar Yield } \\
\text { (t ha- } 1)\end{array}$ & $\begin{array}{c}\text { Remarks } \\
\text { (Rejected due) }\end{array}$ \\
\hline 1 & $\begin{array}{l}\text { S2013-M- } \\
72\end{array}$ & $17.47 p$ & $0.82 \mathrm{k}$ & $52.65 \mathrm{~h}$ & $48.59 \mathrm{k}$ & 5.98 & Smut $\&$ thin cane \\
\hline 2 & $\begin{array}{l}\text { S2013- } \\
\text { US-876 }\end{array}$ & $26.34 \mathrm{i}$ & $1.14 \mathrm{e}$ & $69.42 \mathrm{a}$ & $52.36 \mathrm{f}$ & 6.44 & $\begin{array}{l}\text { High pith \& poor } \\
\text { cane stand }\end{array}$ \\
\hline 3 & $\begin{array}{l}\text { S2013- } \\
\text { US-969 }\end{array}$ & 17.67 o & $1.35 \mathrm{~b}$ & 35.96 o & $32.28 p$ & 3.97 & $\begin{array}{l}\text { Pith \& lodging } \\
\text { trend. }\end{array}$ \\
\hline 4 & $\begin{array}{l}\text { S2014- } \\
\text { SL-347 }\end{array}$ & $32.44 \mathrm{e}$ & $0.98 \mathrm{i}$ & $65.92 \mathrm{~b}$ & 58.37 a & 7.18 & $\begin{array}{c}\text { Aerial roots and } \\
\text { high pith }\end{array}$ \\
\hline 5 & $\begin{array}{l}\text { S2014- } \\
\text { SL-349 }\end{array}$ & $26.39 \mathrm{~h}$ & $0.81 \mathrm{k}$ & $45.13 \mathrm{~m}$ & 36.030 & 4.43 & Smut \\
\hline 6 & $\begin{array}{l}\text { S2014- } \\
\text { SL-353 }\end{array}$ & $19.13 n$ & $1.08 \mathrm{~g}$ & $56.92 \mathrm{e}$ & $48.64 \mathrm{j}$ & 5.99 & $\begin{array}{c}\text { Deep splits, } \\
\text { lodging \& smut. }\end{array}$ \\
\hline 7 & $\begin{array}{l}\text { S2014- } \\
\text { SL-360 }\end{array}$ & $19.31 \mathrm{~m}$ & $1.08 \mathrm{~g}$ & $47.90 \mathrm{k}$ & $50.66 \mathrm{~h}$ & 6.23 & $\begin{array}{l}\text { Deep splits, } \\
\text { lodging \& smut. }\end{array}$ \\
\hline 8 & $\begin{array}{l}\text { S2014- } \\
\text { SL-365 }\end{array}$ & $36.44 \mathrm{c}$ & 0.581 & $48.56 \mathrm{j}$ & $38.87 n$ & 4.78 & $\begin{array}{c}\text { Poor cane } \\
\text { stand\& smut }\end{array}$ \\
\hline 9 & $\begin{array}{l}\text { HSF-240 } \\
\text { (St) }\end{array}$ & $39.54 \mathrm{~b}$ & $1.31 \mathrm{c}$ & $55.52 \mathrm{f}$ & $55.49 \mathrm{c}$ & 6.83 & Check \\
\hline 10 & $\begin{array}{l}\text { CPF-249 } \\
\text { (St) }\end{array}$ & $41.69 \mathrm{a}$ & $1.42 \mathrm{a}$ & $60.41 \mathrm{~d}$ & $58.33 \mathrm{~b}$ & 7.18 & Check \\
\hline 11 & $\begin{array}{l}\text { S2014- } \\
\text { SL-367 }\end{array}$ & $34.42 \mathrm{~d}$ & $1.35 \mathrm{~b}$ & $52.07 \mathrm{i}$ & $54.16 \mathrm{~d}$ & 6.66 & Smut \& pith \\
\hline 12 & $\begin{array}{l}\text { S2014- } \\
\text { SL-380 }\end{array}$ & $27.46 \mathrm{~g}$ & $0.82 \mathrm{k}$ & $43.04 n$ & 47.91 I & 5.89 & Smut \& pith \\
\hline 13 & $\begin{array}{l}\text { S2014- } \\
\text { SL-389 }\end{array}$ & $25.19 \mathrm{j}$ & $0.91 \mathrm{j}$ & $54.84 \mathrm{~g}$ & $49.29 \mathrm{i}$ & 6.06 & Pith \& Smut \\
\hline 14 & $\begin{array}{l}\text { S2014- } \\
\text { SL-396 }\end{array}$ & $30.52 \mathrm{f}$ & $1.01 \mathrm{~h}$ & $55.54 \mathrm{f}$ & $51.37 \mathrm{~g}$ & 6.32 & $\begin{array}{c}\text { Splits, lodging \& } \\
\text { smut }\end{array}$ \\
\hline 15 & $\begin{array}{l}\text { S2014- } \\
\text { JG-525 }\end{array}$ & 21.44 I & $1.12 \mathrm{f}$ & 45.82 I & $45.82 \mathrm{~m}$ & 5.64 & $\begin{array}{l}\text { Lodging \& high } \\
\text { pith }\end{array}$ \\
\hline 16 & $\begin{array}{l}\text { S2014- } \\
\text { SL-592 }\end{array}$ & $23.75 \mathrm{k}$ & $1.17 \mathrm{~d}$ & $63.87 \mathrm{c}$ & $53.47 \mathrm{e}$ & 6.58 & $\begin{array}{c}\text { Rejected due to } \\
\text { Red Rot }\end{array}$ \\
\hline- & $\begin{array}{c}\text { LSD at } \\
0.05\end{array}$ & 0.0125 & 0.0122 & 0.0680 & 5.087 & 0.027 & - \\
\hline
\end{tabular}

In set-II, fourteen clones were studied out of which the clone S2014-SL-1224 gave higher cane yield of $71.51 \mathrm{t} \mathrm{ha}^{-1}$ with $8.73 \mathrm{t} \mathrm{ha}^{-1}$ sugar yield and showed high disease infestation of red rot and smut and so rejected. But S2014-SL-1322, S2014-SL-1359, S2014$\mathrm{SL}-1372$ produced cane yield of $71.37 \mathrm{t} \mathrm{ha}^{-1}, 68.56 \mathrm{t} \mathrm{ha}^{-1,} 67.33 \mathrm{t} \mathrm{ha}^{-1}$ with $8.71 \mathrm{t} \mathrm{ha}^{-1,} 8.34 \mathrm{t}$ $\mathrm{ha}^{-1}, 8.31 \mathrm{t} \mathrm{ha}^{-1}$ sugar yield respectively. These three clones performed well with no bad characters. The remaining twenty five clones (89 \%) out of twenty eight were rejected due to diseases susceptibility, lodging, pithiness, poor crop stand, aerial roots and high splits. These results are in line with the findings of Khan et al., 2008.

The parameters studied in the experiment are as under:

Growth performance. In agronomic practices, the growth performance is related to cane thickness and crop stand. This is character that affects the yield of cane crop. Growth habits, erectness, intermodal length, girth of cane, length of cane depends upon genetic makeup which may be detected by overall performance of clone. In set 1, S2013-US-876 
and S2014-SL-365 showed poor crop stand with thick canes. In set 2, all the fourteen clones showed better growth performance as compared with stand varieties HSF-240 and CPF249.These results are in line with the findings of Kaloi et al., 2007.

Table 2 - Set-II

\begin{tabular}{|c|c|c|c|c|c|c|c|}
\hline $\begin{array}{l}\text { Sr. } \\
\text { No. }\end{array}$ & $\begin{array}{l}\text { Variety / } \\
\text { Clone }\end{array}$ & $\begin{array}{c}\text { Germination } \\
\%\end{array}$ & $\begin{array}{l}\text { Tillers per } \\
\text { Plant }\end{array}$ & $\begin{array}{c}\text { Cane Count } \\
\left(000 \mathrm{ha}^{-1}\right.\end{array}$ & $\begin{array}{c}\text { Cane Yield } \\
\left(\mathrm{t} \mathrm{ha}^{-1}\right)\end{array}$ & $\begin{array}{l}\text { Sugar Yield } \\
\text { (t ha-1) }\end{array}$ & $\begin{array}{c}\text { Remarks } \\
\text { (Rejected due } \\
\text { to) }\end{array}$ \\
\hline 1 & $\begin{array}{c}\text { S2014-SL- } \\
1179 \\
\end{array}$ & $12.87 \mathrm{p}$ & $1.62 \mathrm{f}$ & $62.48 \mathrm{~g}$ & $65.96 \mathrm{e}$ & 8.05 & $\begin{array}{c}\text { Lodging \& } \\
\text { Smut }\end{array}$ \\
\hline 2 & $\begin{array}{c}\text { S2014-SL- } \\
1212 \\
\end{array}$ & $26.24 \mathrm{i}$ & $1.84 \mathrm{a}$ & 59.701 & $62.46 \mathrm{i}$ & 7.62 & $\begin{array}{l}\text { Lodging \& high } \\
\text { pith }\end{array}$ \\
\hline 3 & $\begin{array}{c}\text { S2014-SL- } \\
1215\end{array}$ & $33.43 \mathrm{~g}$ & $0.64 \mathrm{~m}$ & $59.92 \mathrm{k}$ & $59.02 n$ & 7.20 & Red Rot \\
\hline 4 & $\begin{array}{c}\text { S2014-SL- } \\
1224\end{array}$ & $37.68 \mathrm{e}$ & $0.82 \mathrm{k}$ & $68.03 d$ & $71.51 \mathrm{a}$ & 8.73 & $\begin{array}{c}\text { Red Rot \& } \\
\text { Smut }\end{array}$ \\
\hline 5 & $\begin{array}{c}\text { S2014-SL- } \\
1288 \\
\end{array}$ & $24.57 \mathrm{~m}$ & $0.56 \circ$ & $60.42 \mathrm{i}$ & $59.70 \mathrm{~m}$ & 7.29 & $\begin{array}{c}\text { Lodging \& Red } \\
\text { Rot }\end{array}$ \\
\hline 6 & $\begin{array}{c}\text { S2014-SL- } \\
1307\end{array}$ & $44.49 \mathrm{~b}$ & $1.68 \mathrm{~d}$ & $59.01 \mathrm{~m}$ & $62.48 \mathrm{i}$ & 7.62 & $\begin{array}{c}\text { Smut \& Red } \\
\text { Rot }\end{array}$ \\
\hline 7 & $\begin{array}{c}\text { S2014-SL- } \\
1322\end{array}$ & $44.53 \mathrm{a}$ & $1.02 \mathrm{j}$ & $84.54 \mathrm{c}$ & $71.37 \mathrm{~b}$ & 8.71 & $\begin{array}{c}\text { Selected \& } \\
\text { Promoted }\end{array}$ \\
\hline 8 & $\begin{array}{c}\text { S2014-SL- } \\
1336\end{array}$ & $31.52 \mathrm{~h}$ & $0.77 \mathrm{I}$ & 59.711 & $64.56 \mathrm{f}$ & 7.88 & Smut \& Pith \\
\hline 9 & $\begin{array}{l}\text { HSF-240 } \\
\text { (St) }\end{array}$ & 21.820 & $1.64 \mathrm{e}$ & $64.28 \mathrm{f}$ & $60.27 I$ & 7.35 & Check \\
\hline 10 & $\begin{array}{l}\text { CPF-249 } \\
\text { (St) }\end{array}$ & $25.84 \mathrm{j}$ & $1.70 \mathrm{c}$ & $62.49 \mathrm{~g}$ & $63.18 \mathrm{~h}$ & 7.71 & Check \\
\hline 11 & $\begin{array}{c}\text { S2014-SL- } \\
1337\end{array}$ & $34.34 \mathrm{f}$ & $1.47 \mathrm{~h}$ & $62.38 \mathrm{~h}$ & $61.79 \mathrm{j}$ & 7.54 & Red Rot \\
\hline 12 & $\begin{array}{c}\text { S2014-SL- } \\
1351 \\
\end{array}$ & $24.22 n$ & $0.60 n$ & $56.24 n$ & $63.87 \mathrm{~g}$ & 7.79 & $\begin{array}{c}\text { Pith, lodging \& } \\
\text { Smut }\end{array}$ \\
\hline 13 & $\begin{array}{c}\text { S2014-SL- } \\
1359\end{array}$ & $39.59 \mathrm{~d}$ & $1.51 \mathrm{~g}$ & $94.16 \mathrm{a}$ & $68.56 \mathrm{c}$ & 8.34 & $\begin{array}{l}\text { Selected \& } \\
\text { Promoted }\end{array}$ \\
\hline 14 & $\begin{array}{c}\text { S2014-SL- } \\
1362\end{array}$ & $25.57 \mathrm{k}$ & $1.24 \mathrm{i}$ & $60.37 \mathrm{j}$ & $61.08 \mathrm{k}$ & 7.45 & $\begin{array}{c}\text { Pith, lodging \& } \\
\text { Smut }\end{array}$ \\
\hline 15 & $\begin{array}{c}\text { S2014-SL- } \\
1372\end{array}$ & $41.85 \mathrm{c}$ & $1.76 \mathrm{~b}$ & $86.65 \mathrm{~b}$ & $67.33 \mathrm{~d}$ & 8.21 & $\begin{array}{l}\text { Selected \& } \\
\text { Promoted }\end{array}$ \\
\hline 16 & $\begin{array}{c}\text { S2014-SL- } \\
1399\end{array}$ & 25.321 & $1.02 \mathrm{j}$ & $65.56 \mathrm{e}$ & $64.57 \mathrm{f}$ & 7.88 & Red Rot \\
\hline- & $\begin{array}{c}\text { LSD at } \\
0.05\end{array}$ & 0.015 & 0.019 & 0.032 & 6.67 & 0.035 & - \\
\hline
\end{tabular}

Pithiness. Hollow stem with fiber of cane is negative character, leads to lodging, disease infestation and lowers the cane quality. In set 1, four clones S2013-US-876, S2013US-969, S2014-SL-347 and S2014-JG-525 showed presence of pith and so rejected but in set 2, pithiness was seen in any clone. These results are in line with the findings of Khan et al., 2008.

Aerial roots. These are secondary roots which spoil the quality of cane as well as lowers the growth speed and deteriorate crop stand. In set 1, only one clone S2014-SL-347 showed the presence of aerial roots and so rejected. In set 2, aerial roots were not observed in the clones. These results are in accordance with the findings of Kaloi et al., 2007.

Disease infestation. In set 1, smut was seen in clones S2013-M-72, S2014-SL-349, S2014-SL-353, S2014-SL-360, S2014-SL-365,S2014-SL-367, S2014-SL-380, S2014-SL389, S2014-SL-396 and red rot was appeared on S2014-SL-592. In set 2, smut was observed in S2014-SL-1179, S2014-SL-1224, S2014-SL-1307, S2014-SL-1336, S2014-SL1351 and S2014-SL-1362. While red rot was seen on S2014-SL-1215, S2014-SL-1288, S2014-SL-1307, S2014-SL-1337, and S2014-SL-1399. The clones showing the infestation of smut and red rot were rejected. Because these two disease are serious problem under current climate change conditions of Pakistan. These diseases may cause serious yield 
reduction and also it reduces the sugar recovery of crop. These results are in line with the findings of Khan et al., 2008.

Splits. The splits on the stem of cane deteriorate cane quality as well as tissues due to increase in transpiration rate. In set 1, three clones S2014-SL-353, S2014-SL-360 and S2014-SL-396 showed deep splits and cracks in canes. In set 2, splits were not observed in the clones under study. In set 1, the clones showing deep splits / cracks and were rejected. Because the splits reduce cane yield and recovery and also results in the attack of pests and diseases. These results are in line with the findings of Khan et al., 2008 and Kaloi et al., 2007.

Lodging. In set 1, lodging trend was observed in clones S2013-US-969, S2014-SL-353, S2014-SL-360, S2014-SL-396 and S2014-JG-525 and these clones were rejected. In set 2, S2014-SL-1179, S2014-SL-1212, S2014-SL-1288, S2014-SL-1351, S2014-SL-1362, showed low resistance to lodging and were rejected. Because it exerts harmful effects on sugar yield, spoils cane quality and growth of cane crop. It also results in attack of rodents and reduces the sugar recovery of the crops. These results are in line with the findings of Khan et al., 2008 and Kaloi et al., 2007.

\section{CONCLUSION}

In the trial forty seven clones of sugarcane were studied. Fifteen clones were selected and promoted for further study in semi-final trial. The remaining thirty two clones were rejected due to disease susceptibility, pith, lodging and poor growth habits.

\section{REFERENCES}

1. Azam, M. and Mukarram Khan, 2010. Significance of the sugarcane crops with special reference to NWFP. Sarhad J. Agric., 26:289-295.

2. Anonymous, 2017. Economic survey of Pakistan 2016-17. Government of Pakistan.

3. Ahmad, R., Saleem, M. and Nazir, M.S.S., 1991. Autumn ratooning potential of five sugarcane varieties. Pak. J. Agric. Res. 13: 26-29.

4. Bahadar, K., M. Jamal, M. Sadiq, M, Suleman, H, Azim and M.S. Baloch. 2002. Genetic variationand ecological suitability of new sugarcane genotypes under Agro climatic condition of Bannu (NWFP). Pak. Sugar. J. XVII (3): 15-17.

5. Dalvi, S.G., V.C. Vasckar, A. Yadav, P.N. Tawar, G.V. Dixit, T. Prsad and R.B. Deshmukh. 2012. Screening of promising sugarcane somaclones for agronomic traits and smut resistance using PCR amplification of intertran scrip region of Sporisoriumscitaminae. Sugar Tech., 14: 68-75.

6. FAO., 2010. Crop production. Food and Agriculture Organization of the United Nations, Retrieved 17-06-2010.

7. Heinz, D.J. 1987. Sugarcane improvement: Current productivity and future opportunities. International Sugarcane proceeding work. Short Interned reduces recovery increase fiber $\%$ age.

8. Ingelbrecht, I.L., J.E. Irvine and T.E. Mirkov. 1999. Post transcriptional gene silencing in transgenic sugarcane. Plant Physiol., 119: 1187-1198.

9. Junejo, S., G.M. Kaloi, R.N. Panhwar, M. Chohan and. A.F. Soomro. 2010. Performance of some newly developed sugarcane genotypes for some quantitative and qualitative traits under Thatta conditions. J. Ani\& Plant Sci., 20(1): 40-43

10. Javid, M., A. Khatri I. A. Khan, R. Ansari. 2001. NIA 98 a newly sugarcane variety. Agriculture and Technology. The DAWN. Monday, July 16.

11. Kaloi, G.M., D.B. Panhwar, R.N. Panhwar, G.S. Unar, A.H. Mari, M.A. Bhutto and H.K. Keerio. 2007. Thatta-10 a new sugarcane variety for Sindh. Agriculture and Technology. Daily Dawn, Monday August 28, P-3.

12. Khan, I.A., M.U. Dahot, N. Seema, S. Bibi and A. Khatri. 2008. Genetic variability in plantlets derived from callus culture in sugarcane. Pak. J. Bot., 40: 547-564. 
13. Khan, I. A., A. Khatri M. A. Jawed S.H. Saddiqui M. Ahmad N. A. Dahar M .H. Khanzada and R. Khan. 2000. Cane and sugar yield potential of sugarcane line AEC81-8415. Pak. J. Bot., 32 (1): 101-104.

14. Moore, P.H. and K.J. Nuss. 1987. Flowering and flower synchronization inSugarcane Improvement through Breeding, (Ed.): D.J. Heinz, 273-311.

15. Mendoza, E.M.T. 2000. Sugarcane biotechnology trends and prospects for the Philippine sugarcane industry. J. Crop Sci., 25(2): 73-83.

16. Majeedano,H. I, F. M. Baloch, S. D. Twaunio and A. D. Jarwar (2003). Yield response of different sugarcane varieties in Agro-ecological conditions of Tando Jam. Pak. Sugar J., 18(1): 20-23.

17. Sohu , I. A., A.M. Khaskehli, P.A. Baloch and B.A. Abro (2008). Evaluation of yield and yield contributing Parameters of different sugarcane (Saccharumofficnarium, L.,) varieties under National Uniform Varietal Trail. Pak. Sugar. J. XXIII (01): 7-10.

18. Steel, R.G.D. and J.H. Torrie. 1984. Principles and Procedures of Statistics. (McGrawHill: New York).

19. Tiawari, D.K., P. Pandey, R.K. Singh, S.P. Singh and S.B. Singh. 2009. Sugar productivity assessment of newly developed promising genotypes of sugarcane. J. Bio. Sci., 17: 41-44. 